\title{
Peningkatan Aktivitas dan Hasil Belajar Pendidikan Seni Rupa Melalui Penerapan Model Pembelajaran Kontekstual Pada Siswa SMP
}

\section{Ketut Parmada*}

SMP Negeri 3 Sawan, Buleleng, Indonesia

\author{
A R T I C L E I N F O \\ Article history: \\ Received 18 May 2018 \\ Received in revised form \\ 25 June 2018 \\ Accepted 19 July 2018 \\ Available online 26 \\ August 2018

\section{Kata Kunci:} \\ Model Pembelajara \\ Kontekstual; Aktivitas \\ Belajar; Hasil Belajar; \\ Pendidikan Seni Rupa \\ Keywords: \\ Contextual Learning \\ Model; Learning \\ activity; Learning \\ outcomes; Education \\ Art
} dan hasil belajar siswa.

\section{A B S T R A C T}

This study aims to (1) improve student learning activities, (2) improve the learning outcomes of students 'visual practices, and (3) describe students' responses to the contextual learning model in Fine Arts education lessons. The research subjects were students of class VIIA2 SMP Negeri 3 Sawan totaling 27 people. The CAR research was conducted in two cycles. The results showed that there was an increase in students' learning activities in learning art education. In the first cycle and second cycle, the average student learning activities were 2.98 (active enough category) and 3.28 (active type). The learning activities of students experienced quality improvement from the first cycle, the average student learning activity was 2.99 (quite active), and cycle II was the average student learning activity of 3.27 (active). Student learning activities from cycle I to cycle II increased by $0.28 \%$. From the results of learning the practice of fine arts in the first cycle obtained the average class, classical absorption and mastery teaching classically in a row: $70.56,70.56 \%$ and $77.78 \%$. Student responses to the contextual learning model are obtained from the average response class of 45.75. Based on the results of this study, the application of contextual learning models can be used as an alternative to increasing student learning activities and outcomes.

Copyright (c) Universitas Pendidikan Ganesha. All rights reserved.

\footnotetext{
* Corresponding author.

E-mail addresses: parmadaketut@yahoo.co.id (Ketut Parmada)
} 


\section{Pendahuluan}

Pendidikan Pendidikan merupakan suatu hal yang sangat penting karena bertujuan untuk meningkatkan taraf hidup keluarga maupun untuk memajukan kehidupan berbangsa dan bernegara. Maju mundurnya suatu bangsa ini ditentukan oleh tingkat pendidikan yang dimiliki oleh sumber daya manusia (Nurhadi dan Senduk, 2004). Oleh karena itu, pendidikan harus seiring dengan perubahan zaman. Perubahan dan perkembangan aspek kehidupan perlu direspon oleh kinerja pendidikan yang profesional dan berkualitas (Depdiknas, 2003). Mutu pendidikan yang berkualitas dan profesional ini sangat diperlukan agar mampu mendukung kecerdasan kehidupan berbangsa serta mampu bersaing pada era globalisasi.

Begitu pentingnya peran dan tujuan pendidikan maka diperlukan upaya yang dapat dilakukan untuk meningkatkan mutu pendidikan, salah satunya dapat dilakukan melalui peningkatan kurikulum dan tenaga pendidikan secara umum serta pendidikan berbasis keunggulan dan global adalah pendidikan yang memanfaatkan keunggulan dan kebutuhan daya saing global dalam aspek ekonomi, budaya, bahasa, teknologi informasi dan komunikasi, ekologi dan lain-lain yang semuanya bermanfaat bagi pengembangan kompetensi peserta didik. Pemberian kecakapan dan pengetahuan kepada peserta didik yang merupakan proses pembelajaran dilakukan guru di sekolah dengan menggunakan cara-cara atau proses strategi metode pembelajaran tertentu.

Dalam keseluruhan upaya pendidikan, maka proses pembelajaran merupakan aktifitas yang paling penting, karena melalui proses pembelajaran, tujuan pendidikan akan dicapai bentuk perubahan perilaku peserta didik (siswa). Berhasil tidaknya proses pembelajaran ini ditentukan sebagian oleh pribadi pendidik (guru) dan peserta didik yang sedang melakukan proses pembelajaran. Sekolah sebagai lembaga pendidikan membantu mengembangkan potensi yang dimiliki peserta didik melalui proses pembelajaran. Fasilitas, sarana, media, gambar dan tenaga kependidikan merupakan fasilitator yang membantu, mendorong dan membimbing peserta didik dalam proses pembelajaran guna memperoleh keberhasilan dalam belajar.

Proses pembelajaran merupakan inti dari proses pendidikan secara keseluruhan dengan guru sebagai peran utama. Peristiwa pembelajaran banyak berakar pada berbagai pandangan dan konsep. Oleh karena itu perwujudan proses pembelajaran dapat terjadi dalam berbagai model. Bruce Joyce dan Marchal, dalam buru Models of Teaching, dinyatakan tentang 22 model mengajar yang dikelompokkan ke dalam empat hal, yaitu : "(1) proses informasi, (2) perkembangan pribadi, (3) interaksi sosial, dan (4) modifikasi tingkah laku".

Proses pembelajaran merupakan suatu proses yang mengandung serangkaian tindakan atau perbuatan guru dan siswa atas dasar hubungan timbal balik yang berlangsung dalam situasi edukatif untuk mencapai tujuan tertentu. Dalam proses tersirat adanya satu kesatuan kegiatan yang tak terpisahkan antara siswa yang belajar dan guru yang mengajar. Antara kedua kegiatan ini terjalin interaksi yang saling menunjang.

Dalam proses pembelajaran melibatkan interaksi agar siswa dengan guru maupun siswa dengan siswa. Implikasi dari aktifitas siswa memperoleh pemahaman tentang apa yang diperoleh dalam keadaan pembelajaran (Sumanto, 1999). Tercapai tujuan proses pembelajaran diatas, ditentukan oleh berbagai unsur yang menunjangnya (Makmun, 1996) menyatakan bahwa unsur-unsur yang terdapat dalam proses pembelajaran, yaitu: (1) siswa dengan segala karakteristiknya yang berusaha untuk mengembangkan dirinya seoptimal melalui kegiatan belajar, (2) tujuan ialah sesuatu yang diharapkan setelah adanya kegiatan belajar mengajar, dan (3) guru selain mengusahakan terciptanya situasi yang tepat (mengajar), sehingga memungkinkan bagi terjadinya proses pengalaman belajar.

Dari uraian diatas, tampak ada dua posisi subjek, dimana guru sebagai pihak yang mengajar dan siswa sebagai pihak yang belajar. Hal ini mengimplementasikan bahwa dalam proses belajar mengajar merupakan suatu porses interaksi antara guru dan siswa yang didasarkan oleh hubungan yang bersifat mendidik dalam rangka pencapaian tujuan (Surakhmad, 1994).

Kecenderungan terakhir dalam pendidikan adalah pemusatan pada daya kemampuan belajar siswa. Kemampuan belajar ini ditentukan oleh struktur dan perkembangan kognitif siswa, kemampuan belajar dalam lingkungan sosialnya, serta pola persepsi individualnya. Kecenderungan ini ialah mendorong kembalinya perhatian pada pembelajaran terhadap metode mengajar karena kualitas pendidikan formal sebagian ditentukan oleh kualitas pembelajaran.

Mutu pendidikan yang berkualitas dan profesional, sangatlah diperlukan guna ikut berperan membangun kecerdasan kehidupan berbangsa dan mampu berkompetensi dalam globalisasi zaman serta reformasi di bidang pendidikan yang dilaksanakan yang terus melaju pesat dengan kebutuhan pembangunan nasional, yaitu : menyiapkan sumber daya manusia yang andal, terampil, ahli, siap pakai, etos kerja yang tinggi, berbudi luhur, taqwa kepada Tuhan Yang Maha Esa dan bertanggung jawab. Begitu pentingnya peran dan tujuan pendidikan maka diperlukan daya upaya inovasi yang dapat didayagunakan 
guna meningkatkan kualitas pembelajaran melalui pendidikan formal di segala bidang aspek kebutuhan masyarakat, yaitu : budaya ekonomi, termasuk kesenian yang beranekaragam di Indonesia, diantaranya seni tari, seni pahat dan seni lukis serta seni Bahasa Indonesia dan daerah dilestarikan dan dikembangkan pada generasi muda bangsa Indonesia baik melalui pendidikan formal maupun pendidikan nonformal yang lebih baik dan terarah dan berhasil guna.

Sejalan dengan diterapkan Kurikulum 2013 (K-13) maka perlu adanya sistem inovasi pembaharuan metode atau model pembelajaran yang dapat lebih mendorong siswa bergairah belajar, sehingga kelak menghasilkan lulusan yang kompetitif, berbudi luhur, peduli dengan lingkungan, budaya dan kegiatan di masyarakat. Selain itu, peserta didik dimotivasi secara aktif dan kreatif untuk menelaah bahwa kebudayaan seni dan pengalaman mempengaruhi persepsi manusia terasa memiliki pada pelestarian budaya dan seni.

Pengetahuan, keterampilan dan nilai-nilai yang diperoleh dari mata pelajaran seni rupa diharapkan dapat membangun kemampuan peserta didik untuk bersikap bertindak cerdas, aktif, dan bertanggungjawab menghadapi masalah budaya dan kesenian yang harus dikembangkan sebagai generasi penerus.

Melihat dalam kenyataan sekarang ini wujud nyata hasil dalam pengembangan pendidikan pada mata pelajaran seni belum optimal, sehingga perlu perbaikan dan peningkatan sarana dan prasarana pendidikan untuk menunjang mengoptimalkan kualitas pendidikan. Hal tersebut terlihat dari hasil proses pembelajaran di sekolah, dimana siswa pada pembelajaran mata pelajaran pendidikan seni, sangat apatis, sehingga siswa kurang memiliki pengetahuan dasar pendidikan seni. Keadaan ini harus segera diantisipasi untuk ditanggulangi melalui perencanaan dan pendekatan pembelajaran yang dapat lebih menarik simpati siswa agar tumbuh minat belajar menjadi produktif pada pembelajaran pendidikan seni sesuai dengan kemampuan siswa, sehingga siswa merasakan termotivasi belajar pada pendidikan seni yang diajarkan.

Fenomena yang dihadapi siswa kelas VII A2 SMP Negeri 3 Sawan adalah kompetensi guru dalam mengembangkan pendekatan dalam proses metode atau model pembelajaran belum dioptimalkan sehingga hanya terpusat pada guru. Dampak pada pembelajaran mata pelajaran pendidikan seni, siswa menjadi pasif dan perilaku siswa malas belajar, kurang berantusias pada pendidikan seni, keadaan hubungan antar guru dan siswa kurang harmonis, serta keadaan kondusif belajar kurang menggairahkan.

Implikasinya prestasi belajar terlihat pada hasil tes formatif pendidikan seni, dapat dilihat dari hasil pencapaian nilai murni siswa kelas VII A2 SMP Negeri 3 Sawan berdasarkan Buku Nilai Tes Formatif Semester I Bulan Agustus 2017/2018 menunjukkan siswa yang tuntas belajar sebanyak 56\% dan siswa yang belum tuntas belajar sebanyak 44\%. Melihat kondisi tentunya akan jauh dari harapan kompetensi yang berarti memiliki pengetahuan, keterampilan maupun sikap yang dapat dilaksanakan dengan cara berfikir dan bertindak dalam kehidupan sehari-hari (Depdiknas, 2003). Keadaan pada kondisi yang demikian, implikasinya berdampak bagi siswa, sehingga kurang berantusias dan malas belajar dalam mengikuti pembelajaran pada pendidikan seni bidang seni rupa. Ini disebabkan siswa kurang mendapatkan simpati dan perhatian guru melalui pendekatan belajar atau akan kebutuhan belajar. Siswa hanya mendengarkan saja dan tidak diberikan kesempatan baik menyampaikan pertanyaan maupun sumbang pendapat terhadap materi pembelajaran pendidikan seni di bidang seni rupa yang disampaikan oleh guru.

Memperhatikan permasalahan tersebut di atas maka dalam upaya peningkatan mutu pendidikan dan kualitas sumber daya manusia maka permasalahan tersebut di atas harus dapat diatasi dan setidaknya dapat diminimalkan. Untuk itu dipandang perlu mengadakan penelitian dengan focus penerapan model pembelajaran kontekstual (Contextual Teaching Learning atau CTL) pada pembelajaran pendidikan seni rupa dengan alasan adalah: (1) Pembelajaran kontekstual (Contextual Teaching Learning) adalah konsep belajar yang membantu guru mengaitkan antara materi yang diajarkan dengan situasi dunia nyata siswa dan mendorong pada siswa membuat hubungan antara pengetahuan yang dimilikinya dengan penerapan dalam kehidupan sehari-hari, (2) pembelajaran kontekstual dapat merujuk berbagai pengetahuan dan pada pengalaman dalam memecahkan masalah yang dihadapinya, (3) pembelajaran kontekstual diharapkan dapat meningkatkan prestasi belajar dalam keterampilan seni rupa siswa, (4) materi atau pengetahuan bukan semata-mata bersumber atau datang dari guru, tetapi juga ditemukan sendiri oleh siswa itu sendiri, dan dapat lebih memberdayakan siswa sehingga siswa memiliki tujuan yang jelas, (5) kontekstual adalah strategi yang memiliki tujuan tertentu, yaitu agar proses pembelajaran lebih produktif dan bermakna, dan (6) motto pembelajaran adalah cara belajar terbaik, yaitu siswa mengkonstruksi sendiri secara aktif pemahamannya (student learn best by actively constructing their own understanding).

Menurut Saregar (2013) pembelajaran kontekstual atau contextual teaching learning (CTL) adalah pembelajaran yang memungkinkan para siswa mampu menguatkan, memperluas dan menerapkan 
pengetahuan dan ketrampilan akademik mereka dalam berbagai macam tatanan dalam sekolah maupun luar sekola. Pembelajaran kontekstual (contextual teaching and learning) adalah konsep belajar yang membantu guru mengaitkan antara materi yang diajarkan dengan situasi dunia nyata siswa dan mendorong siswa membantu hubungan antara pengetahuan yang dimilikinya dengan penerapannya dalam kehidupan sehari-hari. Pengetahuan dan keterampilan siswa diperoleh dari usaha siswa mengkonstruksikan sendiri pengetahuan dan keterampilan baru ketika ia belajar. Pembelajaran kontekstual terjadi ketika siswa menerapkan dan mengalami apa yang diajarkan dengan mengacu pada masalah-masalah nyata yang berasosiasi dengan peranan dan tanggung jawab mereka sebagai anggota keluarga, masyarakat, siswa dan pelaku kerja. Contextual Teaching and Learning (CTL) adalah pendekatan pembelajaran yang mengkaitkan antara materi yang dipelajari dengan konteks kehidupan sehari-hari siswa (Syahbana, 2012) Di samping itu juga dinyatakan bahwa "pembelajaran kontekstual adalah suatu kegiatan pembelajaran, dimana guru menghadirkan dunia nyata ke dalam kelas dan mendorong siswa membuat hubungan antara pengetahuan yang dimilikinya dengan menerapkannya dalam kehidupan sehari-hari sebagai anggota keluarga dan masyarakat" (Depdiknas, 2002). Pembelajaran kontekstual merupakan sebuah konsep pembelajaran-pengajaran yang membantu guru-guru menghubungkan materi pelajaran dengan situasi dunia nyata; dan memotivasi siswa untuk membuat hubungan antara pengetahuan dan aplikasinya pada kehidupan mereka sebagai anggota keluarga, warga negara, dan pekerja dan terlibat dalam pekerjaan dimana pembelajaran dibutuhkan (Pramitasari, 2011). Contextual Teaching and Learning (CTL) membantu guru mengaitkan materi yang diajarkan dengan situasi dunia nyata siswa dan mendorong siswa membuat hubungan antara pengetahuan yang dimilikinya dengan penerapannya dalam kehidupan mereka sehari-hari (Sulianto, 2008).

Alasan tersebut di atas sesuai dengan apa yang dinyatakan oleh (Dabar, 1989) yang menyatakan bahwa implementasi pembelajaran kontekstual dalam pembelajaran diharapkan dapat menimbulkan suasana belajar bermakna. Memaknai materi pelajaran terjadi, bila pengalaman baru yang dialami oleh siswa dikaitkan dengan pengetahuan-pengetahuan yang selama ini sudah dimiliki siswa. Selanjutnya (Agung, 2005) dinyatakan bahwa pembelajaran bermakna merupakan dan penilaian pribadi yang sangat terkait dengan kepentingan siswa dalam mempelajari materi pelajaran. Pembelajaran dirasakan terkait dengan kehidupan nyata bila siwa mengerti manfaat isi pembelajaran dan mereka merasa berkepentingan untuk belajar demi kehidupannya di masa mendatang. Jadi, pembelajaran kontekstual adalah model pembelajaran yang inovatif, dan dinamis yang esensinya menerapkan tujuh komponen pembelajaran yang efektif yaitu: konstruktivistis, menemukan, bertanya, pemodelan, masyarakat belajar, refleksi dan penilaian autentik.

Berdasarkan rumusan permasalahan di atas maka tujuan penelitian ini adalah sebagai berikut. Pertama, untuk meningkatkan aktivitas belajar dalam pembelajaran pendidikan seni rupa dengan penerapan model pembelajaran kontekstual pada siswa kelas VII A2 SMP Negeri 3 Sawan, Kecamatan Sawan, Kabupaten Buleleng Tahun Pelajaran 2017/2018. Di sisi lain, juga untuk meningkatkan hasil belajar dalam pembelajaran seni rupa dengan penerapan model kontekstual pada siswa kelas VII A2 SMP Negeri 3 Sawan, Kecamatan Sawan, Kabupaten Buleleng Tahun Pelajaran 2017/2018.

\section{Metode}

Masalah yang telah dirumuskan di depan dipecahkan melalui penelitian tindakan kelas, yaitu dengan jalan menerapkan model pembelajaran kontekstual pada siswa kelas VII A2 SMP Negeri 3 Sawan semester II Tahun Pelajaran 2017/2018. Penelitian tindakan kelas ini akan dilaksanakan dalam 2 siklus, yaitu siklus I terdiri dari 7 kali pertemuan dan siklus II terdiri dari 6 kali pertemuan. Materi pembelajaran yang dibahas pada masing-masing siklus seperti terlihat pada Tabel 1.

Tabel 1. Rincian Materi Pembelajaran.

\begin{tabular}{cllc}
\hline Siklus & Pertemuan ke- & \multicolumn{1}{c}{ Materi } & Jumlah Pertemuan \\
\hline & 1,2 dan 3 & $\begin{array}{l}\text { Membuat sket gambar flora,fauna dan geometrik } \\
\text { pada bahan buatan. }\end{array}$ & 3 kali pertemuan \\
I & 4,5 dan 6 & $\begin{array}{l}\text { Membuat karya dua dimensi pada bahan buatan } \\
\text { dengan motif ragam hias flora,fauna dan } \\
\text { geometrik. }\end{array}$ & 3 kali pertemuan \\
II & $1,2,3$ dan 4 & $\begin{array}{l}\text { Membuat pola ragam hias. } \\
\text { Menampilkan karya gambar ragam hias flora. }\end{array}$ & $\begin{array}{l}\text { 4 kali pertemuan } \\
\text { 2 kali pertemuan }\end{array}$ \\
\hline
\end{tabular}


Masing-masing siklus terdiri dari 4 (empat) tahapan, yaitu : (1) perencanaan tindakan, (2) pelaksanaan tindakan, (3) observasi dan evaluasi dan (4) refleksi. Berdasarkan refleksi awal tersebut akan dilakukan penelitian tentang aktivitas dan hasil belajar siswa pada pembelajaran pendidikan seni rupa setelah diterapkan model pembelajaran kontekstual (CTL).

Berdasarkan variabel-variabel yang menjadi objek dalam penelitian ini, maka dapatlah ditentukan jenis data dan instrument yang digunakan untuk mengumpulkan data yang diperlukan dalam penelitian ini seperti yang terlihat pada Tabel 2 .

Tabel 2. Teknik Pengumpulan Data.

\begin{tabular}{|c|c|c|}
\hline No. & Jenis Data & Instrumen \\
\hline 1. & Aktivitas belajar siswa & Lembar observasi \\
\hline 2. & Hasil belajar siswa & Tes hasil belajar \\
\hline 3. & Respon siswa terhadap model pembelajaran yang diterapkan & Kuisioner \\
\hline
\end{tabular}

Aktivitas belajar siswa diamati dengan menggunakan daftar cek. Aktivitas yang dimaksud terdiri dari 5 indikator perilaku siswa, yaitu : 1) Interaksi siswa dengan guru, 2) Interaksi siswa dengan siswa, 3) Kerja kelompok, 4) Aktivitas siswa dalam kegiatan berkarya dengan kelompok, dan 5) Partisipasi siswa dalam menyimpulkan hasil belajar.

Data aktivitas siswa dikumpulkan dengan teknik observasi pada setiap siklusnya. Setiap indicator perilaku masing-masing memiliki 4 deskriptor. Jika satu descriptor dari satuan indicator perilaku teramati, maka siswa tersebut diberi skor 2. Bila 2 deskriptor teramati diberi skor 4 . Bila 4 deskriptor (seluruh deskriptor) teramati diberi skor 5 dan bila tidak teramati diberi skor 1 . Skor aktivitas belajar siswa dieproleh dengan mengalihkan jumlah siswa dengan rata-rata skor yang diperoleh pada tiap-tiap indicator, kemudian dijumlahkan dan dibagi dengan jumlah seluruh siswa dikali dengan jumlah indikator.

Data hasil belajar siswa yang meliputi rata-rata kelas $(x)$ dan ketuntasan klasikal (KK) diperoleh dengan jalan memberikan tes hasil belajar kepada siswa pada akhir siklus.

Respon siswa terhadap pembelajaran dapat dijaring dengan menyebarkan kuesioner model skala Likert dengan penilaian : (1) sangat setuju (SS), (2) setuju (S), (3) ragu-ragu (R), (4) tidak setuju (TS), (5) sangat tidak setuju (STS).

Aktivitas belajar siswa diamati dan dicatat dengan menggunakan pedoman observasi. Data yang diperoleh selanjutnya dianalisis dengan menggunakan analisis statistik deskriptif. Sedangkan data tentang hasil belajar siswa dianalisis dengan menggunakan Mean Kelas. dalam penelitian ini dikatakan berhasil apabila adanya peningkatan nilai siswa setiap siklusnya dari nilai KKM mata pelajaran Seni Budaya SMP Negeri 3 Sawan kelas VII A2 yang sudah ditentukan yaitu $\geq 70$ dan dianggap tuntas belajar jika secara klasikal 85\% dari jumlah siswa memperoleh nilai sekurang-kurangnya 70 dan aktivitas belajar siswa dianggap tuntas apabila sudah mencapai $75 \%$ dari jumlah siswa mendapat kategori Aktif (Depdiknas, 2008)

\section{Hasil dan pembahasan}

Hasil Refleksi Awal Kelas

Pada refleksi awal kelas dalam penelitian ini adalah mengadakan pendekatan dengan guru wali kelas VII A2 SMP Negeri 3 Sawan untuk mengetahui permasalahan yang dihadapi siswa selama ini, pada pembelajaran Pendidikan Seni Rupa. Dari hasil wawancara dengan guru wali kelas, diperoleh informasi bahwa masih ada siswa yang kurang berhasil belajar pada pelajaran Seni Budaya (Seni Rupa), bahwa siswa banyak kurang berminat belajar pembelajaran Seni Rupa, karena selama proses pembelajaran Seni Rupa siswa tidak diberikan kesempatan bertanya jawab atau menyampaikan kesulitan belajar yang dihadapinya. Sehingga dampaknya hasil aktivitas dan hasil belajar siswa menurun, tidak sesuai target pelajaran Pendidikan Seni Rupa sebesar 70 yang dinyatakan tuntas belajar.

Dari hasil penelitian pendahuluan sebelum dilaksanakan tindakan, ternyata di antara 27 siswa yang dinyatakan tuntas belajar hanya 15 orang (56\%), sedangkan yang belum tuntas belajar sebanyak 12 orang (44\%). Melihat kenyataan itu keadaan tersebut tentang keadaan permasalahan yang dihadapi siswa maka dilakukan bimbingan dan pendekatan untuk menumbuhkan minat dan motivasi belajar serta pelatihan Seni Rupa guna meningkatkan hasil prestasi siswa pada Pendidikan Seni Rupa.

Untuk mengetahui sejauh mana daya serap dan keterampilan dalam Seni Rupa maka dilakukan evaluasi melalui Pretest sesuai dengan Pendidikan Seni Rupa. Dasar yang pernah diajarkan pada siswa. Pretest dilaksanakan pada hari Kamis, tanggal 15 Februari 2018 jam 11.00 Wita. Berdasarkan analisis data tersebut, diketahui rata-rata kelas (X) hasil belajar siswa pada adalah 68,0. Dengan jumlah siswa 
yang tuntas sebanyak 15 orang dan ketuntasan belajar yang dicapai sebesar 56\%. Ini berarti belum memenuhi keberhasilan atau belum tuntas, karena Standar Ketuntasan Belajar Minimal (SKBM) sebagai target dalam penelitian ini sebesar 85\%. Atas dasar itu, dipandang perlu adanya perbaikan pelaksanaan proses pembelajaran yang menekankan pada perbaikan pendekatan dan perbaikan pada penggunaan metode pembelajaran yang dikemas dalam model pembelajaran yang inovatif yang dirancang dalam sistem siklus. Pelaksanaan penelitian tindakan kelas ini dilaksanakan dalam dua siklus yang dimulai dari awal bulan Maret 2018 sampai akhir bulan April 2018 pada semester II.

Hasil PTK Siklus I

1) Perecanaan Tindakan

Peneliti menyusun perencanaan tindakan Pendidikan Seni Budaya kelas VII A2 SMP Negeri 3 Sawan dengan langkah-langkah sebagai berikut :

(1) Mempersiapkan pokok bahasan yang akan diajarkan (silabus dan RPP terlampir).

(2) Mempersiapkan kopetensi yang diharapkan pada siswa.

(3) Membuat indikator keberhasilan.

(4) Mempersiapkan alat pembelajaran, metode pembelajaran dan sumber pembelajaran yang digunakan.

(5) Menyusun seperangkat tes hasil belajar.

Penelitian ini dilaksanakan oleh peneliti sebagai guru bidang studi Pendidikan Seni Budaya. peneliti telah menyampaikan maksud dan tujuan serta cara yang harus diterapkan dalam proses pembelajaran. Selanjutnya peneliti sebagai observer yang bertugas memantau kegiatan pembelajaran yang dilaksanakan sebagai guru bidang studi Pendidikan Seni Budaya Kelas VII A2 SMP Negeri 3 Sawan.

2) Pelaksanaan Tindakan

Dalam kegiatan ini peneliti menyuruh guru untuk melaksanakan rencana pembelajaran yang telah disiapkan sebelumnya. Pelaksanaan tindakan dalam sistem siklus setiap siklusnya terdiri dari 4 kali tatap muka masing masing $3 \times 45$ menit dengan rincian sebagai berikut :

(1) Pertemuan I (pertama) mengenai : Memahami prosedur penerapan ragam hias pada bahan buatan

(2) Pertemuan II ( kedua) mengenai : Membuat karya dengan berbagai motif ragam hias pada bahan buatan

(3) Pertemuan III ( ketiga) mengenai : Membuat karya dua dimensi pada bahan buatan dengan motif ragam hias flora,fauna dan geometrik.

(4) Pertemuan IV (keempat) diadakan evaluasi dan post-test untuk mengukur atau mengetahui prestasi belajar siswa.

3) Evaluasi dan Analisis

Untuk mengetahui keberhasilan pelaksanaan pada siklus I, diperlukan adanya evaluasi terhadap proses pembelajaran yang telah dilaksanakan di mana post-test yang terdiri dari evaluasi proses yang dilaksanakan pada akhir siklus I. Evaluasi hasil yang digunakan tes hasil belajar, sedangkan untuk evaluasi proses digunakan metode observasi untuk tes hasil, tes yang digunakan post test dalam bentuk tes praktek membuat karya ragam hias. Tes yang dibuat disesuaikan dengan materi pelajaran yang yang telah dijelaskan atau diajarkan. Pelaksanaan tes diatur sedemikian rupa dengan memperhatikan agar peserta tes dapat bekerja nyaman, tertib, dan mampu membuat karya dalam keadaan menyenangkan. Waktu yang disediakan untuk mengerjakan karya seni rupa selama 30 menit. Hasil yang diproleh dianalisis untuk mencari angka rata - rata atau rerata kelas, Daya serap dan Ketuntasan Belajar. Berdasarkan kriteria klasifikasi aktivitas belajar siswa yang telah ditetapkan diperoleh bahwa aktivitas belajar siswa selama proses pembelajaran siklus I termasuk dalam kategori Cukup Aktif. Analisis data juga menunjukkan bahwa rerata kelas (X) untuk hasil belajar praktek seni rupa siswa pada siklus I sebesar 70,6. Sedangkan daya serap klasikal sebesar 71\%. Dengan jumlah siswa yang tuntas sebanyak 21 orang dan ketuntasan belajar klasikal (KK) yang dicapai sebesar 78\%. Ini berarti belum memenuhi keberhasilan maka perlu dilanjutkan pada siklus II.

Hasil PTK Siklus II

1) Perecanaan Tindakan

Peneliti menyusun perencanaan tindakan Pendidikan Seni Budaya kelas VII A2 SMP Negeri 3 Sawan dengan langkah-langkah sebagai berikut :

(1) Mempersiapkan pokok bahasan yang akan diajarkan (silabus dan RPP terlampir).

(2) Mempersiapkan kopetensi yang diharapkan pada siswa.

(3) Membuat indikator keberhasilan. 
(4) Mempersiapkan alat pembelajaran, metode pembelajaran dan sumber pembelajaran yang digunakan.

(5) Menyusun seperangkat tes hasil belajar.

Penelitian ini dilaksanakan oleh peneliti sebagai guru bidang studi Pendidikan Seni Budaya. peneliti telah menyampaikan maksud dan tujuan serta cara yang harus diterapkan dalam proses pembelajaran. Selanjutnya peneliti sebagai observer yang bertugas memantau kegiatan pembelajaran yang dilaksanakan sebagai guru bidang studi Pendidikan Seni Budaya Kelas VII A2 SMP Negeri 3 Sawan,

2) Pelaksanaan Tindakan

Dalam kegiatan ini peneliti menyuruh guru untuk melaksanakan rencana pembelajaran yang telah disiapkan sebelumnya. Pelaksanaan tindakan dalam sistem siklus setiap siklusnya terdiri dari 4 kali tatap muka masing masing $3 \times 45$ menit dengan rincian sebagai berikut :

(1) Pertemuan I (pertama) mengenai : Menjelaskan fungsi ragam hias, menyebutkan teknik ragam hias pada kayu

(2) Pertemuan II ( kedua) mengenai : Membuat sketsa motif ragam hias flora,fauna,figuratif dan geometrik pada kayu.

(3) Pertemuan III ( ketiga) mengenai : Membuat motif ragam hias geometrik pada kayu.

(4) Pertemuan IV (keempat) diadakan evaluasi dan post-test untuk mengukur atau mengetahui prestasi belajar siswa.

3) Evaluasi dan Analisis

Berdasarkan kriteria klasifikasi aktivitas belajar siswa yang telah ditetapkan, diperoleh rerata respon siswa (X) sebesar 45,70. Berdasarkan kriteria klasifikasi respon siswa yang telah ditetapkan, diperoleh bahwa respon siswa terhadap penerapan model pembelajaran kontekstual (CTL) adalah Sangat Aktif. Di sisi lain, diketahui bahwa rerata kelas $(\mathrm{X})$ untuk hasil belajar praktek seni rupa siswa pada siklus II sebesar $74,8 \%$. Sedangkan daya serap klasikal sebesar 75\%. Dengan jumlah siswa yang tuntas sebanyak 26 orang dan ketuntasan belajar klasikal (KK) yang dicapai sebesar 96,3\%. Ini berarti sudah memenuhi keberhasilan maka penelitian dihentikan pada siklus II.

\section{Pembahasan}

Aktivitas belajar siswa mengalami peningkatan kualitas dari siklus I, diperoleh rata-rata aktivitas belajar siswa 2,99 (Cukup Aktif), dan siklus II rata-rata aktivitas belajar siswa 3,27 (Aktif). Aktivitas belajar siswa dari siklus I ke siklus II meningkat sebesar 0,28\%. Hal ini berarti aktivitas belajar siswa kelas VII A2 SMP Negeri 3 Sawan meningkat melalui penerapan model pembelajaran kontekstual (CTL). Secara umum siswa sudah aktif dalam mengikuti kegiatan pembelajaran, meskipun ada beberapa siswa yang masih kurang aktif. Ini disebabkan oleh beberapa kendala yang dialami dari siklus I sampai siklus II seperti telah diuraikan pada refleksi tiap-tiap siklus.

Dari hasil belajar praktek seni rupa pada siklus I diperoleh rata-rata kelas, daya serap klasikal dan ketuntasan belajar secara klasikal berturut-turut : 70,56, 70.56\% dan 77,78\%. Predikat kelompok yang diperoleh untuk masing-masing kelompok adalah sangat bervariasi ada yang cukup, ada yang baik dan ada juga yang sangat baik. Dengan memperhatikan hasil yang telah diperoleh pada siklus I, ternyata belum sesuai dengan harapan guru. Dari hasil tersebut rata-rata kelas daya serap dan ketuntasan belajar siswa secara klasikal masih tipis mencapai tuntutan Kurikulum yaitu minimal rata-rata 70 dan ketuntasan klasikal 85\%. Hal ini disebabkan karena kendala seperti yang telah diuraikan pada bab III bagian refleksi I. Sesuai dengan refleksi I, maka dilakukan tindakan pada siklus II yang merupakan penyempurnaan dan perbaikan terhadap kendala-kendala yang muncul pada siklus I. Adapun kendala-kendala yang dimaksud adalah sebagai berikut. Pertama, model pembelajaran kontekstual (CTL) menuntut siswa duduk dengan siswa lain dalam kelompoknya masing-masing. Pada siklus I waktu banyak tersita untuk mencari teman satu tim dan mencari tempat duduk sesuai dengan kelompoknya. Untuk mengatasi hal ini maka pada siklus II kelompok dibagikan terlebih dahulu sebelum proses pembelajaran berlangsung. Dan siswa diwajibkan sudah duduk dengan kelompoknya sebelum proses pembelajaran dimulai. Kedua, kurangnya kerja sama antar kelompok siswa cenderung bekerja sendiri-sendiri dalam tugas yang diberikan, sehingga dalam pengerjaan tugas praktek ini memerlukan waktu yang lama. Hal ini menyebabkan proses pembelajaran seni menjadi kurang efektif. Untuk mengatasi hal ini guru mengarahkan siswa untuk mengadakan pembagian dalam berkarya secara berkelompok. Dimana setiap anggota kelompok mendapat kesempatan diberikan untuk berkarya secara teratur dan kondusif keadaan di ruangan kelas.

Kendala selanjutnya adalah pada saat siswa bekerja dalam kelompok, siswa jarang memanfaatkan kelompok. Siswa biasanya langsung bertanya kepada guru tanpa terlebih dahulu berdiskusi antar 
kelompoknya masing-masing. Siswa biasanya langsung bertanya kepada guru, apabila ada hal-hal yang belum jelas. Hal ini dilakukan tanpa terlebih dahulu berdiskusi dengan kelompok masing-masing. Walaupun diantara anggota kelompok ada yang dapat menjawab permasalahan tersebut. Hal ini menyebabkan interaksi diantara siswa menjadi sangat kurang harmonis dalam kegiatan berkarya di ruangan kelas atau diluar. Untuk mengatasi hal tersebut guru tidak langsung menjawab pertanyaan siswa. Tetapi guru terlebih dahulu bertanya kepada anggota kelompok lain, apakah ada yang mengerti dengan pertanyaan tersebut. Jika salah satu dari anggota kelompok telah memahami pertanyaan anggota lainnya maka guru meminta siswa tersebut untuk menjelaskan kepada teman sejawat yang berada dalam satu kelompoknya. Hal ini dapat memperlancar interaksi dan komunikasi antar siswa dalam satu kelompok. Disamping itu siswa dapat menemukan jawaban sendiri berdasarkan hasil diskusi kelompok.

Keempat, beberapa siswa biasanya malu bertanya kepada peneliti karena merasa rendah diri. Mereka lebih banyak pilih diam dan menonton saja bahkan malah senang bikin hura-hura antar kawannya yang sedang bekerja. Hal ini sangat mempengaruhi pemahaman siswa terhadap permasalahan yang akhirnya akan mempengaruhi hasil belajar yang diperolehnya. Untuk mengatasi masalah ini, maka guru memberikan dorongan atau motivasi kepada siswa dengan kesempatan untuk menyampaikan segala kesulitan yang dihadapi siswa dan langsung mendapat tanggapan dan diperhatikan. Agar siswa berani bertanya atau menyampaikan pendapat. Cara yang dilakukan dengan menunjuk siswa untuk menanggapi atau menjawab kesulitan yang dihadapinya. Kendala terakhir, guru mengajak siswa bertanya untuk membahas LKS yang sudah dikerjakan. Hal ini dilakukan dengan jalan menunjuk siswa secara acak agar seluruh siswa siap-siap untuk menjawab soal latihan yang diberikan oleh guru, apabila siswa ditunjuk. Sehingga dengan cara ini siswa dapat lebih diarahkan kembali untuk berkonsentrasi pada pelajaran.

Setelah diadakan penyempurnaan dan perbaikan terhadap kendala-kendala yang dialami pada siklus I, maka pada siklus II diperoleh rata-rata kelas sebesar 74,81, daya serap klasikal $74,81 \%$ dan ketuntasan klasikal yaitu : 96,30\%. Jika dibandingkan dengan hasil belajar pada siklus I, maka terjadi peningkatan sebesar 4,25\%. Predikat kelompok yang diperoleh untuk masing-masing kelompok mengalami peningkatan yaitu ada kelompok baik dan sangat baik. Peningkatan hasil belajar praktek berkarya seni, ini disebabkan karena tindakan-tindakan perbaikan yang telah peneliti lakukan, sehingga kemampuan siswa untuk berkarya seni rupa lebih meningkat pada siklus II dan membawa dampak positif terhadap peningkatan aktivitas serta hasil belajar siswa.

Siswa kelas VII A2 SMP Negeri 3 Sawan memberikan respon yang positif terhadap penerapan model pembelajaran kontekstual (CTL). Hal ini dapat dilihat dari sebaran angket yang diberikan kepada siswa dengan skor rata-rata respon siswa 45,71 dan peningkatan hasil praktek belajar seni rupa secara klasikal. Secara umum penelitian PTK ini dapat dikatakan berhasil, karena mampu menghasilkan aktivitas dan hasil belajar praktek seni rupa yang tinggi pada siswa kelas VII A2 SMP Negeri 3 Sawan dan penelitian ini dapat meningkatkan aktivitas dan hasil praktek belajar seni rupa daftar siswa kelas VII A2 SMP Negeri 3 Sawan, jika dibandingkan dengan hasil yang diperoleh sebelum penerapan model-model pembelajaran kontekstual (CTL). Hal ini sesuai dengan hasil dari Ratmini (2001) yang menyatakan bahwa penerapan model kontekstual (CTL) dapat meningkatkan aktivitas dan hasil belajar siswa.

\section{Simpulan dan saran}

Penerapan model pembelajaran kontekstual dalam pembelajaran pendidikan seni rupa dapat meningkatkan aktivitas belajar pada siswa kelas VII A2 semester I SMP Negeri 3 Sawan. Pada siklus I, skor aktivitas belajar siswa sebesar 2,99 dan siklus II skor aktivitas belajar siswa sebesar 3,27. Ini berarti terjadi peningkatan aktivitas belajar siswa dari siklus I ke siklus II sebesar 0,28\%. Secara kualitatif, aktivitas siswa juga mengalami peningkatan dari tergolong Cukup Aktif pada siklus I menjadi Aktif pada siklus II. Di sisi lain, penerapan model pembelajaran kontekstual dalam pembelajaran pendidikan seni rupa dapat meningkatkan hasil belajar praktek seni rupa kelas VII A2 SMP Negeri 3 Sawan. Dari siklus I ke siklus II terjadi peningkatan skor rata-rata kelas sebesar 4,25\% yaitu dari 70,56\% menjadi 74,81\%. Daya serap klasikal meningkat dari siklus I ke siklus II 4,25\%. Dari siklus I ke siklus II terjadi kenaikan ketuntasan klasikal 18,52\% yaitu dari 77,78\% menjadi 96,30\%.

\section{Daftar Rujukan}

Agung, A. A. G. 1999. Metodologi Penelitian Pendidikan. Singaraja : STKIP Singaraja.

Anggraeni, Diah. 2013. Meningkatkan Kemampuan Pemahaman Dan Komunikasi Matematik Siswa Smk Melalui Pendekatan Kontekstual Dan Strategi Formulate-Share Listen-Create (FSLC). Infinity Journal, Vol. 2, No.1. 
Ardana, I.M. 2007. Beberapa Model Pembelajaran Inovatif Sebagai Antisipasi Pelaksanaan KTSP. Singaraja : Universitas Pendidikan Ganesha.

Arikunto, S. 1993. Dasar-Dasar Evaluasi Pendidikan. Jakarta : Bumi Aksara.

Dahar, S.W. 1999. Teori-Teori Belajar. Jakarta : Erlangga.

Depdiknas. 2002. Kurikulum Berbasis Kompetensi. Jakarta : Depdiknas.

Depdiknas. 2003. Sistem Penilaian Kelas SD, SMP, SMA. Jakarta.

Ganda Putra, Fredi. 2017. Eksperimentasi Pendekatan Kontekstual Berbantuan Hands On Activity (HoA) Terhadap Kemampuan Pemecahan Masalah Matematik. Jurnal Pendidikan Matematika. Vol.8, No.1.

Hamalik, O. 2002. Psikhologi Pendidikan. Bandung : Bumi Aksara.

James, P. dan Bakar, Eva L. 2005. Teknik Mengajar Secara Sistematis. Jakarta : Rineka.

Margono. 2000. Metodologi Penelitian Pendidikan. Jakarta : Rineka.

Masita, Meici. 2012. Peningkatan Aktivitas Siswa Pada Pembelajaran Matematika Melalui Pendekatan Kontekstual (Contextual Teaching And Learning). Jurnal Pendidikan Mataram, Vol.1, No.1.

Muhammad, S. 2004. Psikologi Pembelajaran. Bandung : Sinar Baru.

Mulhamah, \& Putrawangsa, S. 2016. Penerapan Pembelajaran Kontekstual dalam Meningkatkan Kemampuan Pemecahan Masalah Matematika. Jurnal Pendidikan Matematika, 10(1), 58-80.

Nasution. 2000. Berbagai Pendekatan dalam Proses Belajar Mengajar. Bandung : Bumi Aksara.

Nurhadi dan Senduk. 2003. Pembelajaran Kontekstual dan Penerapannya dalam KBK. Malang : Universitas Malang.

Nurkancana dan Sumartana. 1993. Evaluasi Pendidikan. Surabaya : Usaha Nasional.

Pramitasari, Amelia dkk. 2011. Hubungan Antara Persepsi Terhadap Metode Pembelajaran Kontekstual Dengan Motivasi Belajar Biologi Siswa Kelas XI IPA SMAN 1 Pangkalan Kerinci, Riau. Jurnal Psikologi Undip, Vol.9, No.1.

Saregar, Antomi dkk. 2013. Pembelajaran Fisika Kontekstual Melalui Metode Eksperimen Dan Demonstrasi Diskusi Menggunakan Multimedia Interaktif Ditinjau Dari Sikap Ilmiah Dan Kemampuan Verbal Siswa. Jurnal Inkuiri, Vol.2, No.2.

Sariningsih, Ratna. 2014. Pendekatan Kontekstual Untuk Meningkatkan Kemampuan Pemahaman Matematis Siswa SMP. Infinity Journal, Vol.2, No.3.

Sudjarwa. 1989. Beberapa Aspek Pengembangan Sumber Belajar. Jakarta : Media Tama.

Sulianto, Joko. 2008. Pendekatan Kontekstual Dalam Pembelajaran Matematika Untuk Meningkatkan Berpikir Kritis Pada Siswa Sekolah Dasar. Jurnal Matematika, Vol.4, No.2.

Suryabrata, S. 1993. Psikologi Pendidikan. Jakarta: Erlangga.

Syaiful, B. 2000. Guru dan Anak Didik dalam Interaksi Edukatif. Jakarta : Rineka.

Syahbana, Ali. 2012. Pengembangan Perangkat Pembelajaran Berbasis Kontekstual Untuk Mengukur Kemampuan Berpikir Kritis Matematis Siswa SMP. Edumatica, Vol. 2, No.2.

Tabrani, R. A. 1993. Proses Belajar yang Efektif Tingkat Pendidikan Dasar. Bandung : Bina Budhaya. 
Winarno, S. 1979. Strategi Proses Pembelajaran yang Efektif. Bandung : Angkasa.

Widiati, Indah. 2015. Mengembangkan Kemampuan Representasi Matematis Siswa Sekolah Menengah Pertama Melalui Pembelajaran Kontekstual. Jurnal Pengajaran MIPA, Vol.20, No.2.

Yayat, N. 2002. Kesenian Tari Nusantara. Jakarta : Balai Pustaka. 